\title{
SIMULATOR DESIGN OF KARTINI REACTOR BASED ON LABVIEW
}

\author{
Sinta Uri El Hakim¹, Adi Abimanyu ${ }^{1}$, Sutanto ${ }^{1}$ \\ 1) Department of Nuclear Technophysics, Sekolah Tinggi Teknologi Nuklir-BATAN, \\ J1. Babarsari Kotak POB 6101/YKKB Sleman, D.I.Yogyakarta 55281 \\ uriel.hakim@gmail.com, abimanyu.adi@batan.go.id, sutanto5381@batan.go.id
}

\begin{abstract}
SIMULATOR DESIGN OF KARTINI REACTOR BASED ON LABVIEW. Kartini reactor's simulator design has been designed using LabVIEW software as a simulation engine. The reactor is used as training tools for engineer or technician to operate reactor. Moreover, It is also utillized as an educational purpose for studying kinetics model of reactor. The simulator is designed using reactor kinetic model to imitate the dynamics of Kartini's Reactor. The simulator acquires the changes of height position of control Rod as data input and provide information on reactor power to the user. The numerical test has been done to evaluate the performance of the simulator in imitating the operation of the reactor during transient and steady state condition. For example, $100 \mathrm{~kW}$ reactor power is obtained by changing the control rod position such as $100 \%$ position of Safety rod, $60 \%$ for Shim rod, and $37.05 \%$ for Regulator rod. The numerical test also demonstrated that the regulator rod position will be highly affected by the changes of Shim rod position and the full power operation is achieved in various position of the regulator rod.
\end{abstract}

Key words: LabVIEW. Reactors Kinetics, simulation

\section{RESEARCH BACKGROUND}

Kartini Nuclear Reactor located in Yogyakarta regency is a TRIGA (Training Research and Isotope production General Atomic) reactor type which has negative temperature reactivity coefficient, so it can be categorized as inherent safety reactor [1]. TRIGA Mark II is a research reactor designed and commisioned by General Atomic that uses water as coolant and moderator [2]. TRIGA Mark II reactor is utilized in various field such as Neutron Activation Analysis (AAN), Radiography and Neutron Tomography, education and training [3].

The process of power regulating in the Kartini reactor is done by moving the control rods subsequently to obtain gradual power increase, since sudden rod increments may lead to scram [4]. Scram is an emergency stop of nuclear reactor operation due to the reactor operates beyond the specified limits which is determined by the insertion of control rod into the reactor core [5]. The position of the control rod in the nuclear reactor plays a crucial role to control nuclear reaction and power generation.
The process of power increase in the reactor is limited by period. Based on Pinto et al (2013) [6] Period is the time it takes for a neutron to develop in accordance with its reactor power.

Utilization of nuclear reactors requires an operation management to minimize unforce scram event [7]. Therefore, the reactor control simulator is important to provide repetitive training since it capable to simulate process in slower performance [8].

There are several simulator that have been designed to help researcher learn more about control and algorithm before it was applied on the real situation, as reported by Moh. Rosyid [5] Kartini Reactor Reactor as a Research Model Device TRIGA Mark II. Meanwhile Patricia Reis [9] conducted a study on Simulation of a TRIGA Reactor Core Block Using RELAP5 Code in Brazil. Beside that Pinto et al (2013) [6] have done a research with the title of Operatinal Parameter Study of IPRRI Triga Research Reactor Using Virtual Instrument. A lot of researcher had build several reactor in simulator because it is pretty dangerous if we applied directly the modeling 
algorithm into reactor.

Based on the description above, it is necessary to build a Kartini reactor simulator to support the training of operator of reactor Kartini to reduce the occurrence of unforced scram as well as finding the perfect algorithm that could be possibly applied on the reactor. Besides that, this simulator could help the education field as a learning system for student to understand more about reactor kinetics modeling.

\section{Kartini Reactor}

Kartini reactor is a TRIGA reactor (Training Research and Isotope production of General Atomic) Mark II, that is a $250-\mathrm{kW}$ research reactor designed and manufactured by General Atomic using light water with graphite reflectors arranged circularly in the reactor [10]. The Kartini reactor is designed based on a pool reactor system, with Uranium Zirconium Hydride (U-ZrH) fuel enriched up to $20 \%$. The reactor core is composed of a combination of fuel elements and a moderator resulting in a negative temperature coefficient of ( 1.5 cent dollars $\left./{ }^{\circ} \mathrm{C}\right)$ [11]. Kartini reactor is used for training, education, and development of nuclear research [12]. Figure 2 shows the sideways look from Kartini Reactor. The three control rods used in this TRIGA Mark II type reactor are: Control Regulator (R), Shim (C), and Safety (S) [13]. The three control rods have the same shape and size. The position of the control rod in the core of the reactor is shown in Figure 1. Regulator control rod is located on the ring E1, while the compensation control rod (Shim) and the Safety control rod are respectively located in the rings $\mathrm{C} 9$ and $\mathrm{C} 5$.

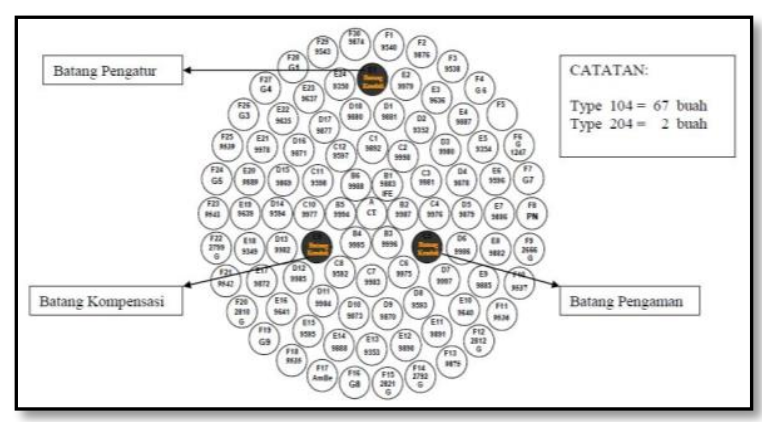

Figure 1 Control Rod Position in Reactor Core

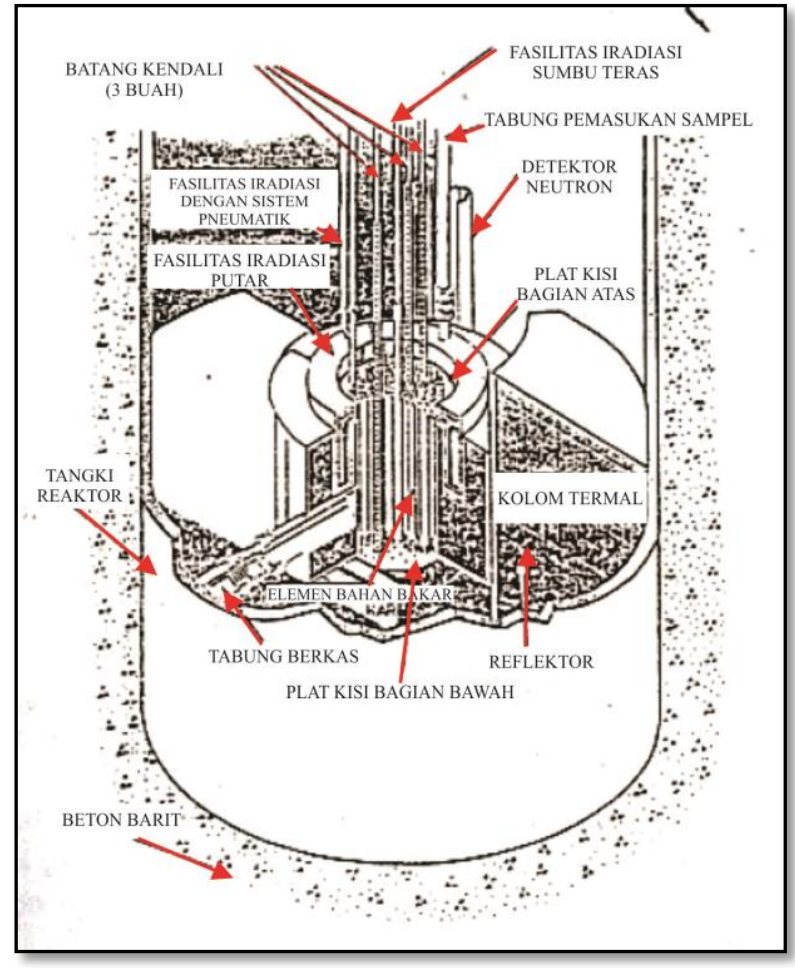

Figure 2 Sideways of Kartini Reactor

\section{Point Kinetics Model}

Neutron behavior in the nuclear reactor is shown by the reactor kinetics equation. The simplest equation is the kinetic equation in the point reactor model. This equation is derived from the equilibrium of the neutron population in the core with the assumption that a single, thermal, homogenous reactor is independent of the space variable. Reactor kinetics is calculated using Eq. (1) and Eq. (2).

$$
\begin{aligned}
& \frac{d}{d t} n(t)=\frac{\rho(t)-\beta}{\square} n(t)+\sum_{i=1}^{6} \lambda_{u} C_{i}(t)+S(t) \\
& \frac{d}{d t} C_{i}(t)=\frac{\beta_{i}}{\square} n(t)-\lambda_{i} C_{i} t
\end{aligned}
$$

$$
\begin{array}{ll}
\text { With } & \\
\mathrm{n}(\mathrm{t}) & =\mathrm{t} \text { neutron (neutron } / \mathrm{cm}^{3} \text { ) } \\
\mathrm{Ci}(\mathrm{t}) & =\text { delayed neutron precursor } \\
& \text { concentration at- } \mathrm{i} \\
\rho(\mathrm{t}) & =\text { core total reactivity at- } \mathrm{t} \\
\beta \mathrm{i} & =\text { delayed neutron fraction at-i } \\
\beta & =\text { delayed neutron } \\
\lambda \mathrm{i} & =\text { decay constant of delayed neutron } \\
& \text { at-i (second-1) } \\
\ell & =\text { neutron generation lifetime } \\
& \text { (second) } \\
\mathrm{S} & =\text { level source of neutron } \\
& \text { (neutron } / \mathrm{cm}^{3} \text {.second) }
\end{array}
$$




\section{Conversion of Position Rod}

In the calculation of the reactor simulation, it is necessary to consider the conversion formulation of control rod position changes into reactivity to be calculated using reactor kinetics equation written in Eq. (1). The value of reactivity can be calculated from the value of the control rod position changes using Eq. (3) [14].

$$
\begin{aligned}
& \Delta \rho(x) \\
& =\rho\left(\frac{x}{H}-\frac{1}{2 \pi} \sin \frac{2 \pi x}{H}\right)
\end{aligned}
$$

With

$$
\begin{array}{ll}
\rho & =\text { control rod worth }(\$) \\
\Delta \rho(\mathrm{x}) & =\text { delta reactivity }(\$) \\
\mathrm{H} & =\text { height of active reactor core }(38 \\
& \mathrm{cm}) \\
\Delta \rho(\mathrm{x}) & =\text { delta reactivity due to full } \\
& \text { insertion }
\end{array}
$$

\section{Power Conversion}

The calculation of reactor kinetics using equations (1) and (2) provide neutron density that will be converted into power using Eq. (4)[15].

$$
P=\frac{\sum f \phi V_{r}}{3,125 \times 10^{10}}
$$

$\mathrm{P} \quad=$ reactor power (watt)

$\Sigma_{\mathrm{f}} \quad=$ macroscopic cross section $\left(\mathrm{cm}^{-1}\right)$

$\phi=$ neutron flux (neutron $/ \mathrm{cm}^{2}$.second)

$\mathrm{V}_{\mathrm{r}} \quad=$ core volume $\left(\mathrm{cm}^{3}\right)$

$3.125 \times 10^{10}=$ core fission coefficient

$$
\sum f=N \times \sigma_{f}
$$

$$
N=\frac{N_{A} m}{V B A}
$$

The macroscopic latitude depends on the core fission coefficient that have been produced. The macroscopic latitude is formulated according to Eq. (5). While the density of the material can be split formulated in accordance with Eq. (6) [15].

\section{RESEARCH METHODOLOGY}

The design of the Kartini reactor simulator was done by implementing the reactor kinetics equation into LabVIEW software. This simulator using point kinetic models to simulate neutronic properties that happened in Kartini's Reactor Changes in the control rod will result in a power change according to the reactor kinetics equation.

\section{Design of the Simulator}

The reactor kinetics equations are embodied in the LabVIEW program as a data acquisition and data processing system. The data from the control rod changes will be converted to reactivity changes as shown successively in Figures 3 and 4. In Figure 3 it can be seen that there are OPC Server Out_Safety, Out_Shim and Out_Reg libraries. These libraries connect PLC with program in LabVIEW. Changes in the position of the control rod will be read by LabVIEW through these three Tags. While Figure 4 shows the contents of Sub VI, in example the conversion equation changes the position of the control rod to changes in reactivity. From Sub VI this results in the form of changes in total reactivity of the three control rods with units of dollars (\$) 


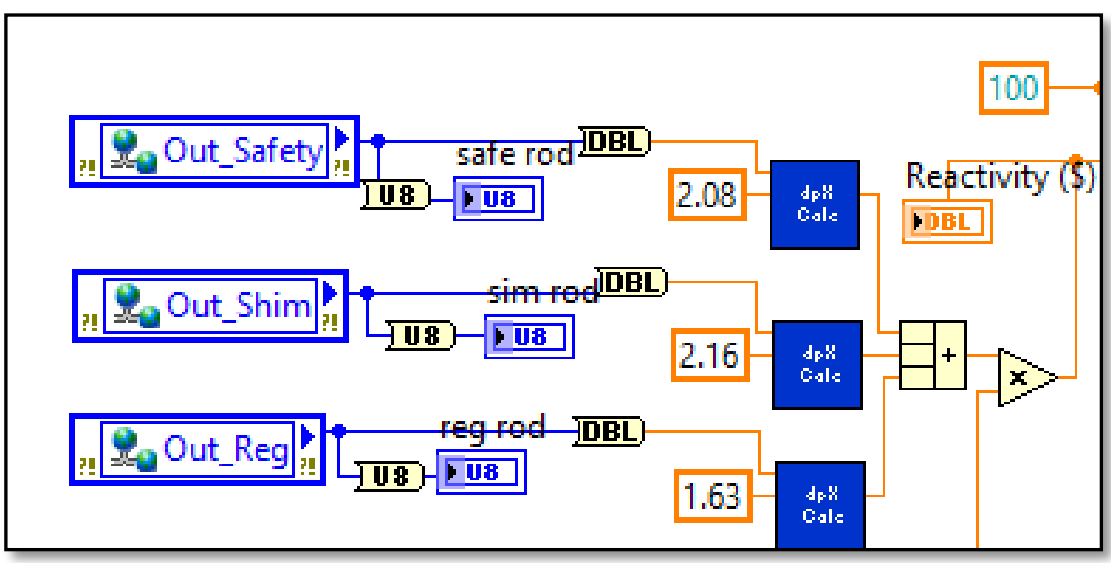

Figure $3 \mathrm{Sub}$ VI for the conversion counts of position changes of the control rod into a reactivity changes (According to reactivity Rod of Kartini Reactor)

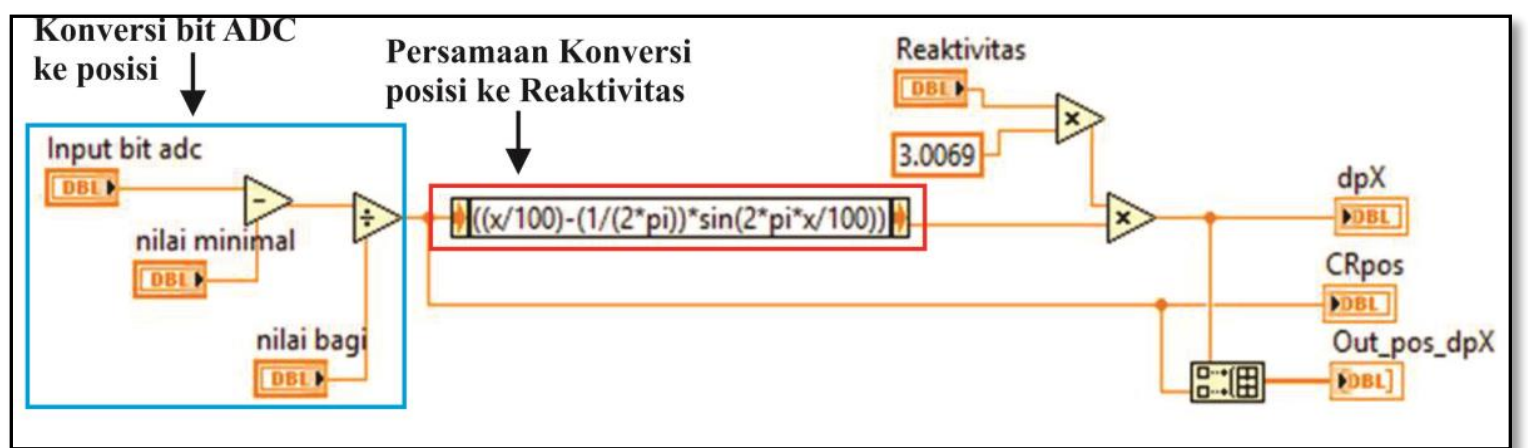

Figure 4 Position changes conversion of the control rod into the reactivity changes embodied in Sub VI

The changes of reactivity then used to calculate the neutron density. The reactor point kinetics equations model is built into LabVIEW following such algorithm [16]:

1. Determining the initial value for neutron density (NO), initial concentration of neutron precursor $(\mathrm{C} 0)$, initial effectiveness $\left(\rho_{0}\right)$, delayed neutron fraction $(\beta)$, time of delayed neutron generation $(\Lambda)$, decay constant of delayed neutron $(\lambda)$.

2. Determining the time increment, $h$

3. Calculating the changes of neutron density over the time $(\mathrm{dN} / \mathrm{dt})$

4. Calculating the changes of delayed neutron precursor concentration over the time $(\mathrm{dC} / \mathrm{dt})$

5. Calculate the neutron density for time $(\mathrm{t}$ $+h$ ) by multiplying the previous neutron density by increment time, h, plus the neutron density at time $t$.

6. Calculating the precursor concentration of the cervical neutrons for time $(t+h)$ by multiplying the precursor concentration of the previous neutron precursor by increment time, h, plus the concentration of the calibrated neutron precursor at time $t$.

Based on the algorithm, it can build a data changes position of the control rod into neutron density processing program. The Reactor kinetic LabVIEW program can be seen in Figure 5. In Figure 5, the main program of the reactor kinetics is inserted for a loop with 1000 count iterations. The number of $\beta i$ and $\lambda i$ values are obtained from the group data of the neutronproducing neutron nuclides from the fission results of $\mathrm{U} 235$. 


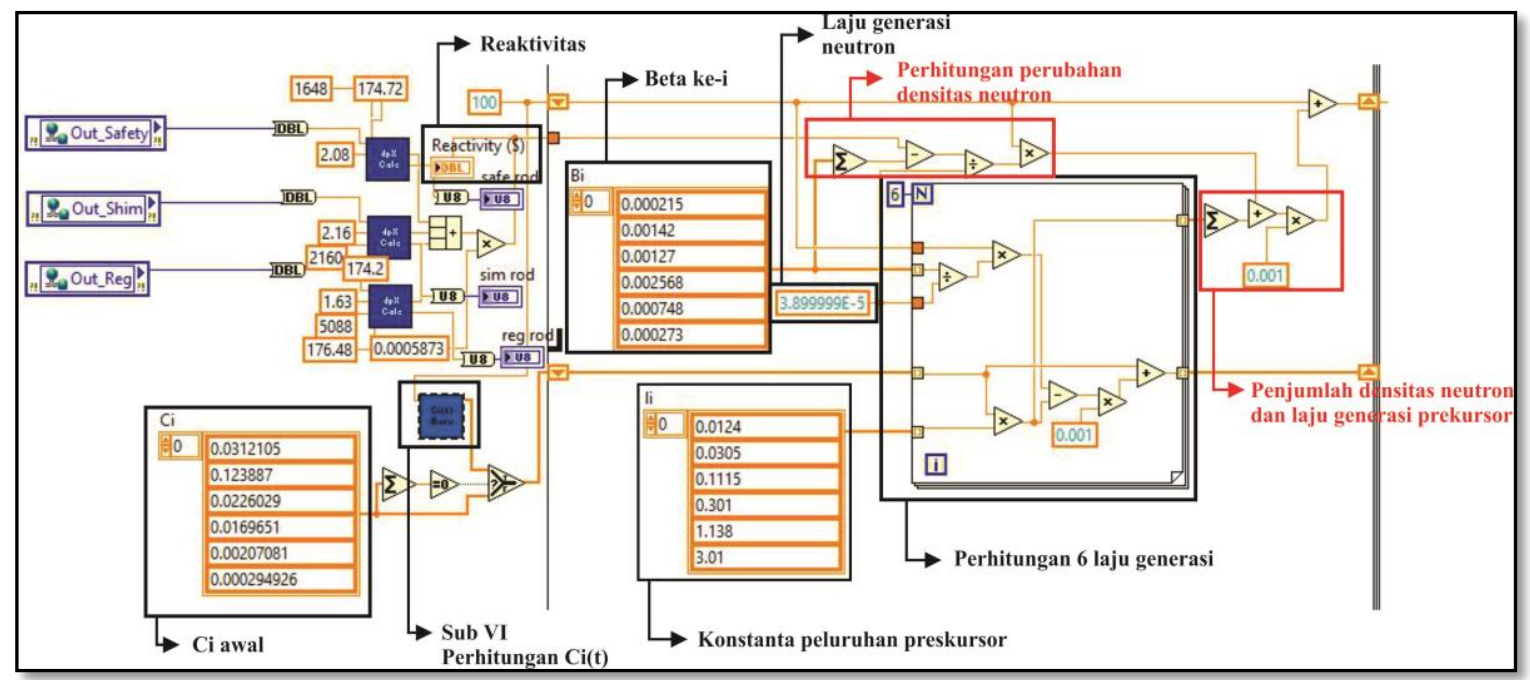

Figure 5 Point Kinetics Model Equation build into LabVIEW program (Applied on Reactor Simulator in Indonesia)

After obtaining the neutron density from the calculated program of Figure 5, the neutron density will be converted to reactor power by Eq. (3). In the calculation of neutron density, it is required calculation of the rate of precursor neutrons. The neutron precursor rate calculation program is built based on Eq. (2). The neutron precursor rate program can be seen in Figure 6.

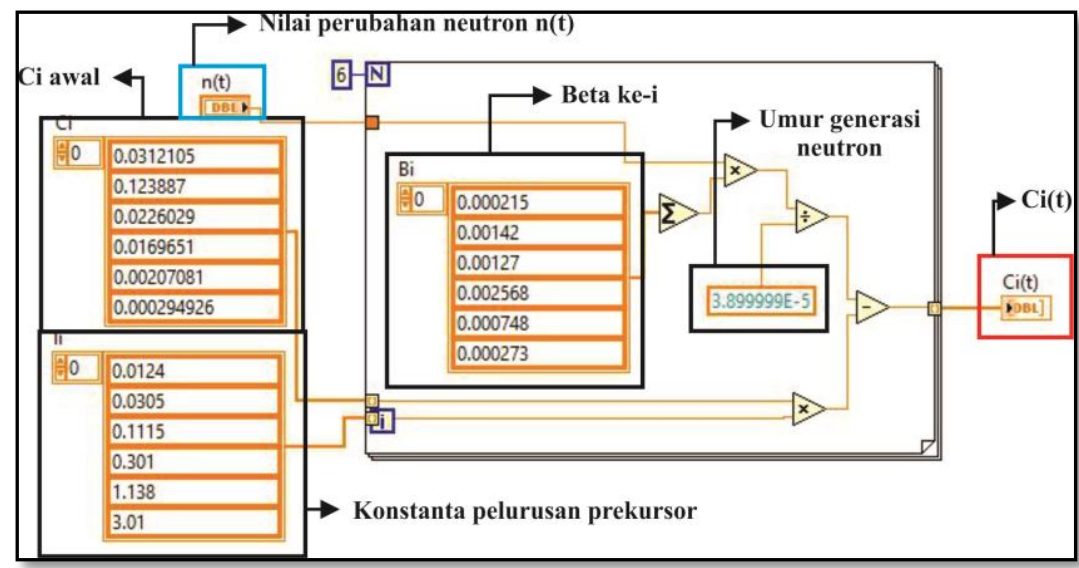

Figure 6 The calculation of $\mathrm{Ci}(\mathrm{t})$ number $(\mathrm{Ci}(0)$ Number according to Kartini Reactor that is in Indonesia)

After obtaining the amount of neutron density that have been produced, then the density will be converted into power. The equation is embodied in the LabVIEW program as shown in Figure 7. Reactor power that have been generated is shown in watts units. 


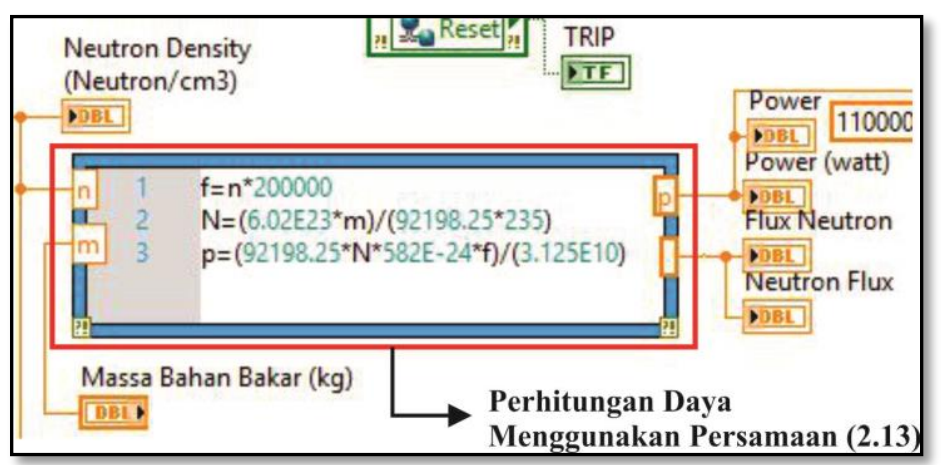

Figure 7 Neutrons density into Power conversion LabVIEW program

\section{RESULT AND DISCUSSION}

The results obtained from the running program can be seen in Table 1, Table 2, and Table 3. Based on the results shown by Table 1 with the initial setting of $100 \%$ safety control bar rod and $60 \%$ shim control rod, $10 \mathrm{~kW}$ of power will be achieved if the regulator control rod Increased by $34.70 \%$. The setting of regulator control rod position to raise power up to $100 \mathrm{~kW}$ based on data from running program is $36.90 \%$.

The data obtained from Table 1 yields a graph of power change to the position changes of the control rod as shown in Figure 8 and Figure 9. Based on Fig. 8 the increase of regulator control rod appears very tight (slight change in position) to provide the increase of power up to $10 \mathrm{~kW}$. Based on Figure 9 it can be seen that the decrease in the control rod provides a similar value when raising the control rod. The

Table 1 Results of running programs with 100\% Safety Position and Shim 60\%

\begin{tabular}{cccc}
\hline \multicolumn{2}{c}{ Control Rod Up } & \multicolumn{2}{c}{ Control Rod Down } \\
\hline $\begin{array}{c}\text { Regulator } \\
\boldsymbol{U} \boldsymbol{p}\end{array}$ & $\begin{array}{c}\text { Power } \\
(\mathbf{k W})\end{array}$ & $\begin{array}{c}\text { Regulator } \\
\text { Down }\end{array}$ & $\begin{array}{c}\text { Power } \\
(\mathbf{k W})\end{array}$ \\
\hline $0,00 \%$ & 0.00 & $37.05 \%$ & 100.00 \\
$34,70 \%$ & 10.00 & $36.93 \%$ & 90.00 \\
$35,45 \%$ & 20.00 & $36.83 \%$ & 80.00 \\
$35,86 \%$ & 30.00 & $36.70 \%$ & 70.00 \\
$36,15 \%$ & 40.00 & $36.55 \%$ & 60.00 \\
\hline
\end{tabular}

tightly changing position of the regulator control rod starts when the power reaches 10 $\mathrm{kW}$ to $100 \mathrm{~kW}$. Meanwhile, to increase the power from $0 \mathrm{~kW}$ up to $10 \mathrm{~kW}$ require a large regulator rod change that is $34.70 \%$.

When the control rod is lowered the reactor power will also decrease due to the negative reactivity that have been provided. The position of the control rods is gradually decreased from $100 \mathrm{~kW}$ to $0 \mathrm{~kW}$ as shown in Table 1. In Table 1, it can be seen that the position of the regulator control rod when lowered to a certain power tends to be close to the same as the regulator control rod as it is raised. For example, it can be seen at $10 \mathrm{~kW}$ power, to achieve $10 \mathrm{~kW}$ power, it is necessary to increase the control rod up to $34.70 \%$ position, and when it is lowered to $10 \mathrm{~kW}$ power, the regulator control rod position obtained is approximately equal to $34.74 \%$

\begin{tabular}{cccc}
\hline \multicolumn{2}{c}{ Control Rod Up } & \multicolumn{2}{c}{ Control Rod Down } \\
\hline $\begin{array}{c}\text { Regulator } \\
\boldsymbol{U} \boldsymbol{p}\end{array}$ & $\begin{array}{c}\text { Power } \\
(\mathbf{k W})\end{array}$ & $\begin{array}{c}\text { Regulator } \\
\text { Down }\end{array}$ & $\begin{array}{c}\text { Power } \\
(\mathbf{k W})\end{array}$ \\
\hline $36,37 \%$ & 50.00 & $36.37 \%$ & 50.00 \\
$36,38 \%$ & 60.00 & $36.15 \%$ & 40.00 \\
$36,55 \%$ & 70.00 & $35.86 \%$ & 30.00 \\
$36,70 \%$ & 80.00 & $35.49 \%$ & 20.00 \\
$36,83 \%$ & 90.00 & $34.74 \%$ & 10.00 \\
$36,90 \%$ & 100.00 & $0.00 \%$ & 0.00 \\
\hline
\end{tabular}


JURNAL FORUM NUKLIR (JFN) VOLUME 12, NOMOR 1, MEI 2018

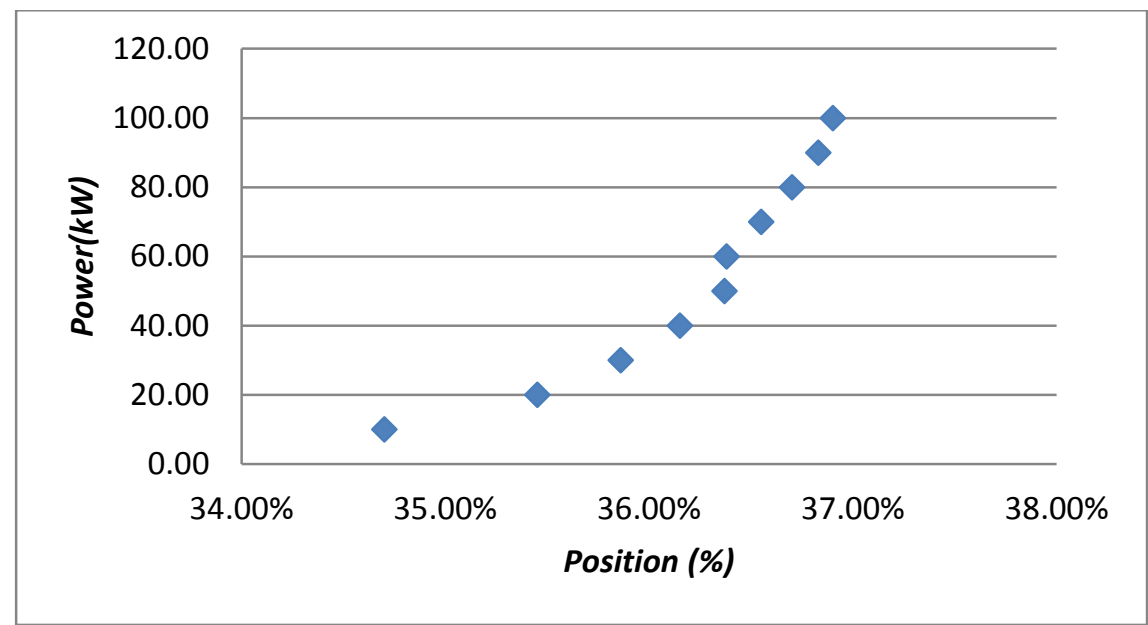

Figure 8 Power Graph against the changes of Regulator Up (100\% safety position and 60\% shim)

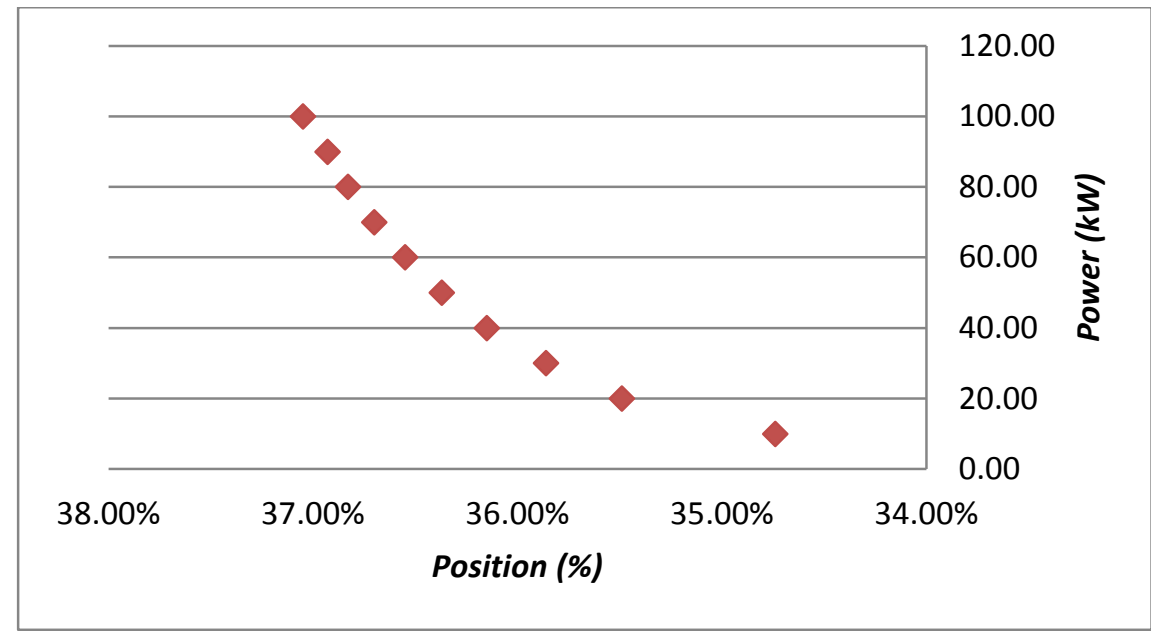

Figure 9 Power Graph against the changes of Regulator Down (100\% safety position and 60\% shim)

In the second running program, shim control rod positions is set to $65 \%$ position while the safety control rod position remains at $100 \%$. The result of the running program are shown in Table 2. When the Shim control rod position is at $65 \%$, it is required the withdrawal of regulator control rod $26.3 \%$ to obtain $10 \mathrm{~kW}$ of power. While to obtain $100 \mathrm{~kW}$ of power require the withdrawal of regulator control rod in the position of $29.5 \%$.

Figure 10 shows the position of the control rod whenever an increase in power occurs due to the changes in the position of the regulator control rod. While in Figure 11 shows the change of control rod position down to $0 \%$ position. The graph generated from the decrease of control rod position has a similar value as the raised control rod as shown in Figure 11. Figure 10 shows the slight changes of regulator control rod position to provide a power boost of $10 \mathrm{~kW}$. This small changing position of the regulator control rod begins when power reaches $10 \mathrm{~kW}$ to $100 \mathrm{~kW}$. Meanwhile, to increase the power from $0 \mathrm{~kW}$ up to $10 \mathrm{~kW}$, it require a large regulator control rod change that is $26.3 \%$.

When the control rod is lowered, the reactor power will also decrease due to the negative reactivity that have been provided. The position of control rods is gradually decreased from $100 \mathrm{~kW}$ to $0 \mathrm{~kW}$ as indicated by Table 2 . In Table 2 it can be seen that the position of the regulator control rod when lowered to a certain power tends to be similar to the regulator control rod when raised up. For example, to achieve 10 $\mathrm{kW}$ of power, control rod is raised up to $26.30 \%$ position, and when lowered to $10 \mathrm{~kW}$ power the regulator control rod position is equal to $26.30 \%$. 
Table 2 Results of running programs with 100\% Safety Position and Shim 65\%

\begin{tabular}{cccc}
\hline \multicolumn{2}{c}{ Control Rod Up } & \multicolumn{2}{c}{ Control Rod Down } \\
\hline $\begin{array}{c}\text { Regulator } \\
\boldsymbol{U} \boldsymbol{p}\end{array}$ & $\begin{array}{c}\text { Power } \\
(\mathbf{k W})\end{array}$ & $\begin{array}{c}\text { Regulator } \\
\text { Down }\end{array}$ & $\begin{array}{c}\text { Power } \\
(\mathbf{k W})\end{array}$ \\
\hline $0,00 \%$ & 0,00 & $29,50 \%$ & 100.00 \\
$26,30 \%$ & 10,00 & $29,30 \%$ & 90.00 \\
$27,30 \%$ & 20,00 & $29,20 \%$ & 80.00 \\
$27,90 \%$ & 30,00 & $29,00 \%$ & 70.00 \\
$28,30 \%$ & 40,00 & $28,80 \%$ & 60.00 \\
\hline
\end{tabular}

\begin{tabular}{cccc}
\hline \multicolumn{2}{c}{ Control Rod Up } & \multicolumn{2}{c}{ Control Rod Down } \\
\hline $\begin{array}{c}\text { Regulator } \\
\boldsymbol{U} \boldsymbol{p}\end{array}$ & $\begin{array}{c}\text { Power } \\
(\mathbf{k W})\end{array}$ & $\begin{array}{c}\text { Regulator } \\
\text { Down }\end{array}$ & $\begin{array}{c}\text { Power } \\
(\mathbf{k W})\end{array}$ \\
\hline $28,60 \%$ & 50,00 & $28,60 \%$ & 50.00 \\
$28,80 \%$ & 60,00 & $28,30 \%$ & 40.00 \\
$29,00 \%$ & 70,00 & $27,90 \%$ & 30.00 \\
$29,20 \%$ & 80,00 & $27,30 \%$ & 20.00 \\
$29,30 \%$ & 90,00 & $26,30 \%$ & 10.00 \\
$29,50 \%$ & 100,00 & $0,00 \%$ & 0,00 \\
\hline
\end{tabular}

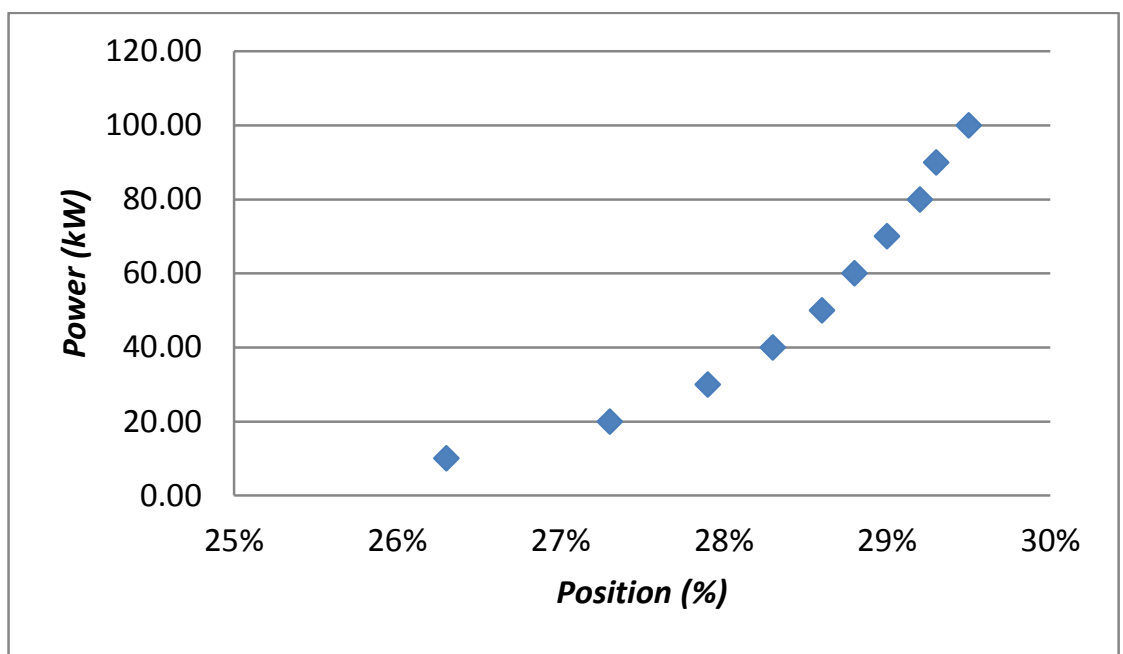

Figure 10 Power Graph against the changes of Regulator Up (100\% safety position and 65\% shim)

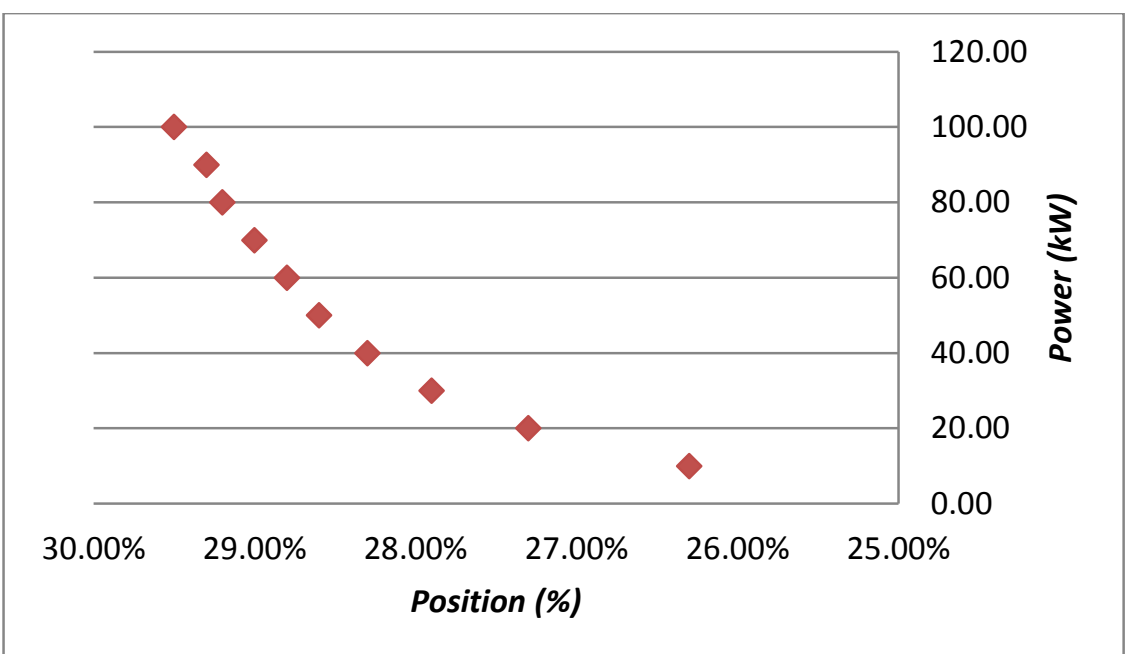

Gambar 11 Power Graph against the changes of Regulator Up (100\% safety position and 65\% shim)

In the third running program, the shim control rod position is set to $70 \%$ position while the safety control rod position stays at $100 \%$. The result of running program are exhibited in Table 3. When the shim control rod position is at $70 \%$, to obtain $10 \mathrm{~kW}$ of power, it require a withdrawal of regulator control rod up until $10.06 \%$. But the shim-control rod position at $70 \%$ enabled to generate power of $0.03 \mathrm{~kW}$. To obtain $100 \mathrm{~kW}$ of power, it require a withdrawal of regulator control rod up until $19.50 \%$. 
Figure 12 shows the slight changes of regulator control rod position to provide a power boost of $10 \mathrm{~kW}$. While in Figure 13 shows that lowering regulator control rod down gives similar trendline as the raised control rod's bar. The tight changes of regulator control rod position begins when power reaches $10 \mathrm{~kW}$ to $100 \mathrm{~kW}$. To raise the power from $0.03 \mathrm{~kW}$ to 10 $\mathrm{kW}$, it requires a large increase regulator rod control equal to $10.6 \%$.

When the control rod is lowered, the reactor power will also decrease due to the

Tabel 3 Hasil running program dengan Posisi Safety $100 \%$ dan shim $70 \%$

\begin{tabular}{cccc}
\hline \multicolumn{2}{c}{ Control Rod Up } & \multicolumn{2}{c}{ Control Rod Down } \\
\hline $\begin{array}{c}\text { Regulator } \\
\boldsymbol{U} \boldsymbol{p}\end{array}$ & $\begin{array}{c}\text { Power } \\
(\mathbf{k W})\end{array}$ & $\begin{array}{c}\text { Regulator } \\
\text { Down }\end{array}$ & $\begin{array}{c}\text { Power } \\
(\mathbf{k W})\end{array}$ \\
\hline $0 \%$ & 0.03 & $19,50 \%$ & 100.00 \\
$10,6 \%$ & 10.00 & $19,30 \%$ & 90.00 \\
$14,50 \%$ & 20.00 & $19 \%$ & 80.00 \\
$16,10 \%$ & 30.00 & $18,60 \%$ & 70.00 \\
$17 \%$ & 40.00 & $18,20 \%$ & 60.00 \\
\hline
\end{tabular}

negative reactivity that have been provided. The position of control rods is gradually decreased from $100 \mathrm{~kW}$ to $0 \mathrm{~kW}$ as indicated by Table 3 . It can be seen that the position of regulator control rod, when lowered to a certain power, is relatively similar to that of raised regulator control rod. For example, to achieve $10 \mathrm{~kW}$ of power, control rod is raised up to $10.60 \%$ position, and when lowered to $10 \mathrm{~kW}$ of power, the position of regulator control rod is equal to $10,60 \%$.

\begin{tabular}{cccc}
\hline \multicolumn{2}{c}{ Control Rod Up } & \multicolumn{2}{c}{ Control Rod Down } \\
\hline $\begin{array}{c}\text { Regulator } \\
\boldsymbol{U} \boldsymbol{p}\end{array}$ & $\begin{array}{c}\text { Power } \\
(\mathbf{k W})\end{array}$ & $\begin{array}{c}\text { Regulator } \\
\text { Down }\end{array}$ & $\begin{array}{c}\text { Power } \\
(\mathbf{k W})\end{array}$ \\
\hline $17,70 \%$ & 50.00 & $17,70 \%$ & 50.00 \\
$18,20 \%$ & 60.00 & $17 \%$ & 40.00 \\
$18,60 \%$ & 70.00 & $16,10 \%$ & 30.00 \\
$19 \%$ & 80.00 & $14,50 \%$ & 20.00 \\
$19,30 \%$ & 90.00 & $10,6 \%$ & 10.00 \\
$19,50 \%$ & 100.00 & $0 \%$ & 0,03 \\
\hline
\end{tabular}

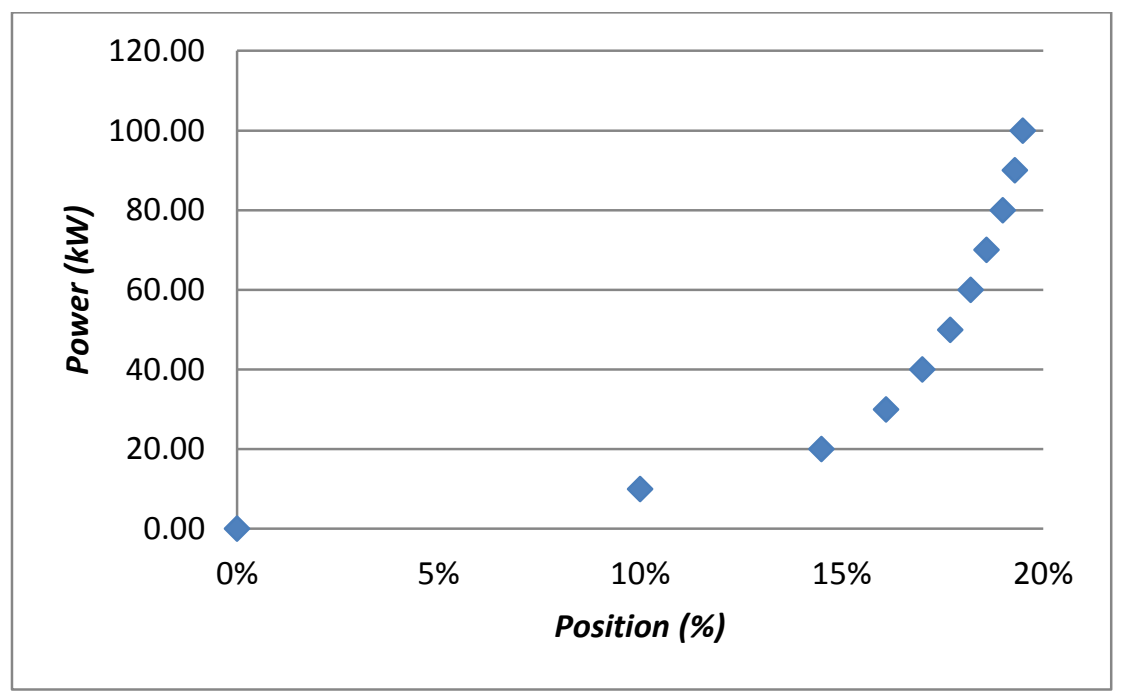

Figure 12 Power Graph against the changes of Regulator Up (100\% safety position and 70\% shim) 
JURNAL FORUM NUKLIR (JFN) VOLUME 12, NOMOR 1, MEI 2018

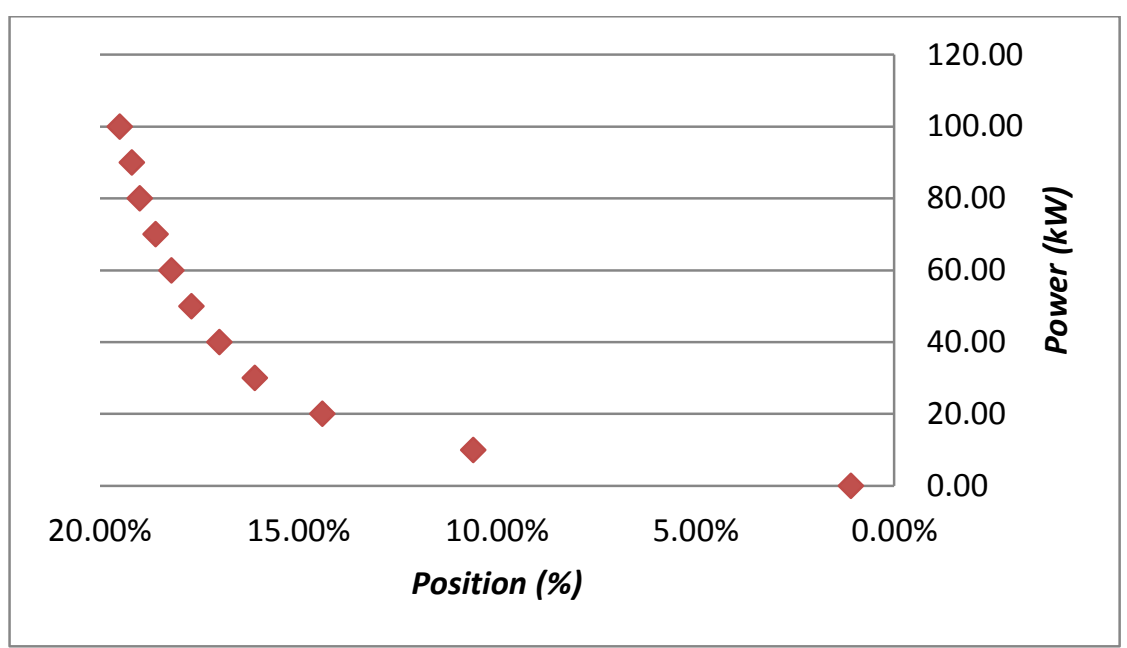

Figure 13 Power Graph against the changes of Regulator Up (100\% safety position and $65 \%$ shim)

To achieve the same power, it will require the different position of either regulator and shim control rods. This is because the reactivity of the shim control rod greatly affects the increase of power in the reactor operation.

The position of the regulator control rod will be different if the shim rod control position setting is also different. Based on the running program in Figure 14, when the shim position is set to $60 \%$, the reactivity result is $0.00631931 \$$. The reactivity is smaller than shim position at $70 \%$ that is $0.00692079 \$$ as shown in Figure 15. So at the time of shim position at $60 \%$, it will give a result in a higher regulator position than shim position at $70 \%$

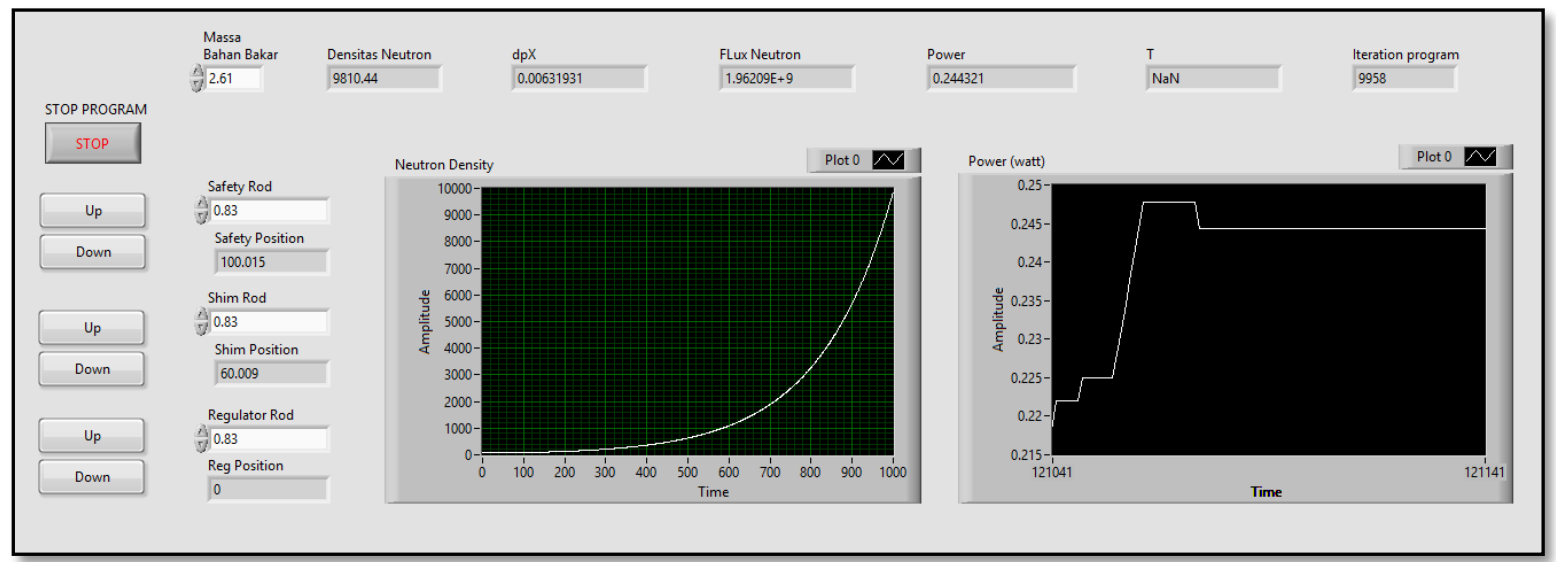

Figure 14 Reactor Operation with $60 \%$ position of Shim control rod 


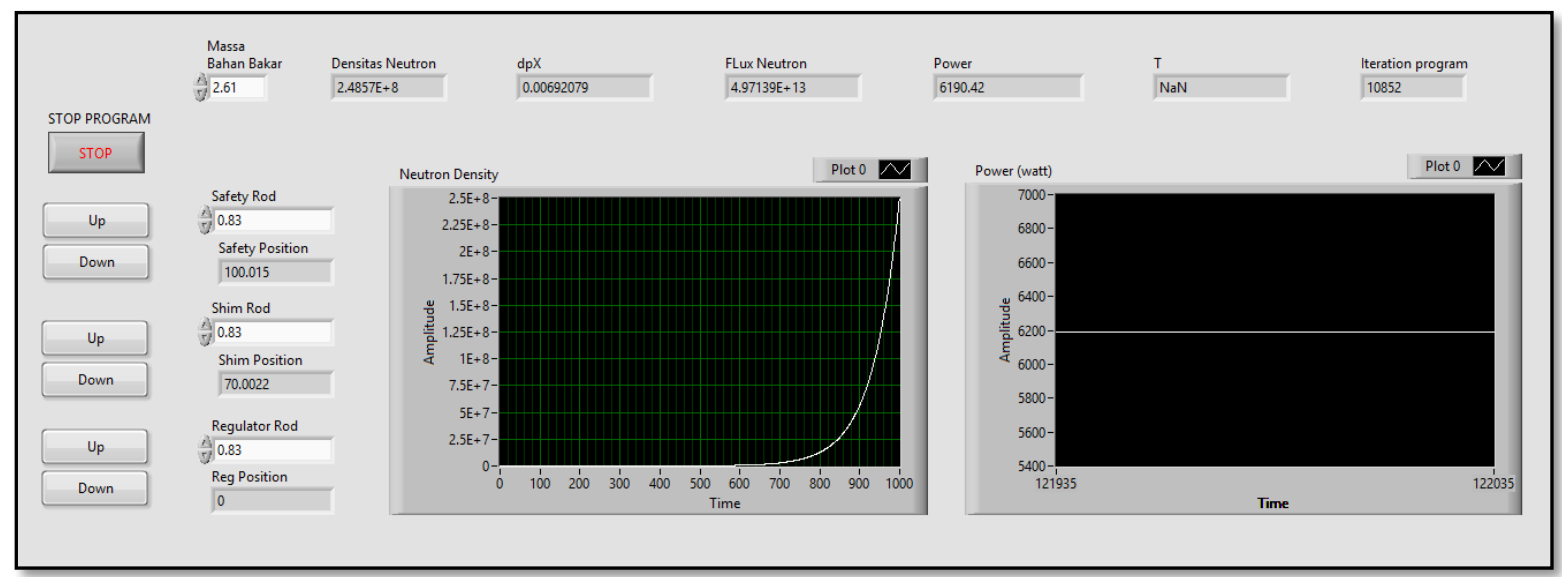

Figure 15 Reactor Operation with 70\% position of Shim control rod

Comparison between Simulations and Reactor Operations

The results of running programs that have been obtained will be compared with the data from Kartini reactor operation when performing power operations. The data of the simulation has different number with the data generated from Kartini reactor operation. It is because the Kartini reactor is influenced by

several things other than reactor kinetics, such as fuel temperature, coolant

Tabel 4 Comparison Result between

Simulation and Reactor Operation

\begin{tabular}{ccccc}
\hline No & $\begin{array}{c}\text { Control } \\
\text { Rod }\end{array}$ & $\begin{array}{c}\text { Position } \\
\text { (Simulation) }\end{array}$ & $\begin{array}{c}\text { Position } \\
\text { (Operation) }\end{array}$ & $\begin{array}{c}\text { Faktor } \\
\text { Pengali }\end{array}$ \\
\hline 1 & Safety & $100 \%$ & $100 \%$ & 1 \\
& Shim & $60 \%$ & $60 \%$ & 1 \\
& Regulator & $37.05 \%$ & $55 \%$ & 1.46 \\
2 & Safety & $100 \%$ & $100 \%$ & 1 \\
& Shim & $65 \%$ & $65 \%$ & 1 \\
\hline
\end{tabular}

Based on the data in Table 4 of the simulation results which is compared with the data from the operation results, such informations can be implied. At the time of $100 \%$ safety position, $60 \%$ shim has a multiplier factor of 1.46 for the simulated position of the regulator to have a value that is not much different from the actual reactor operation. When the safety position is at $100 \%$, and shim at $65 \%$ shows multiplier factor equals to 1.59 . When the safety position at $100 \%$, shim at $70 \%$, the obtained multiplier is 2.13 . density, source level, xenon poisoning (Xe) and several other parameters. While the

simulation is built using only reactor kinetics equation and influenced by the change of reactivity due to the changes of control rod position.

\begin{tabular}{ccccc}
\hline No & $\begin{array}{c}\text { Control } \\
\text { Rod }\end{array}$ & $\begin{array}{c}\text { Position } \\
\text { (Simulation) }\end{array}$ & $\begin{array}{c}\text { Position } \\
\text { (Operation) }\end{array}$ & $\begin{array}{c}\text { Faktor } \\
\text { Pengali }\end{array}$ \\
\hline \multirow{2}{*}{3} & Regulator & $29.50 \%$ & $47 \%$ & 1.59 \\
& Safety & $100 \%$ & $100 \%$ & 1 \\
& Shim & $70 \%$ & $70 \%$ & 1 \\
& Regulator & $19.50 \%$ & $41.60 \%$ & 2.13 \\
\hline
\end{tabular}

\section{CONCLUSION}

The research to design Reactor Simulator of Kartini Reactor have been conducted. In conclusio, achieving $100 \mathrm{~kW}$ power can be done with 3 way positioning settings :

1. Safety control rod at $100 \%$, shim control rod at $60 \%$, and regulator control rod at $37.05 \%$.

2. Safety control rod at $100 \%$, shim control rod at $65 \%$, and regulator control rod at $29.50 \%$. 
3. Safety control rod at $100 \%$, shim control rod at $70 \%$, and regulator control rod at $19.05 \%$.

\section{SUGGESTION}

The simulations built using LabVIEW is only to consider the reactor kinetics equation to perform the calculation of control rod position changes into neutron density. Fuel temperature and coolant density are ignored, so the simulation results have not been validated with Kartini reactor operation results. For the future, it is suggested to continue author's research by adding a feedback reactivity program which consists of fuel temperature calculation and coolant density.

\section{DAFTAR PUSTAKA}

1. A. Suntoro, " Logic Circuit of MAnual Power Control Interlock Analysis in Reactor Kartini" in Seminar Nasional III SDM Teknologi Nuklir, 2007, pp. 21-22.

2. A. Cammi, M. Zanetti, D. Chiesa, M. Clemenza, S. Pozzi, E. Previtali, et al., "Characterization of the TRIGA Mark II Reactor Full-Power Steady State," Nuclear Engineering and Design, vol. 300, pp. 3008-321, 2016.

3. R. Henry, I. Tiselj, and L. Snoj, "Analysis of JSI TRIGA Mark II Reactor Physical Parameters Calculated with TRIPOLI MCNP," Applied Radiation and Isotopes, vol. 97, pp. 140-148, 2015.

4. Marsudi and Rochim, " Installation of Monitor System On Kartini Reactor Aid System" in Peningkatan Kemampuan Peneliti dan Perekayasa (PKPP) 2007.

5. M. Rosyid, N. Hidayat, and Jumari, " Kartini Reactor Simulator as Kartini Reactor Operation Reactor Research TRIGA Mark II" in Seminar Nasional
IX SDM Teknologi Nuklir, Yogyakarta, 2013.

6. A. J. Pinto, A. Z. Mesquita, and F. S. Lameiras, "Operational Parameters Study of IPR-RI TRIGA Research Reactor Using Virtual Instruments," presented at the 22nd International COngres of Mechanical Engineering (COBEM 2013), Brazil, 2013.

7. IAEA, IAEA Nuclear Energy Vienna: IAEA, 2008.

8. K. P. d. K. R. I. Kemdikbud, "KBBI Daring," ed, 2016.

9. P. A. L. Reis, A. L. Costa, C. Pereira, M. A. F. Veloso, and A. Z. Mesquita, "Simulation of TRIGA Reactor Core Blokage Using RELAP5 Code," Science and Technology of Nuclear Installations, vol. 2015, p. 10, 2015.

10. M. Ravnik. (1998, 23 December). Description of TRIGA Reactor.

11. H. S. Setijawan, "Start-Up System and Automatic Power Control Based on Microcomputer" Jurusan Teknik Nuklir, Universitas Gadjah Mada, Yogyakarta, 1994.

12. H. Bock, M. Villa, and R. Bergmann, "Five Decades of TRIGA Reactor," presented at the 25th Internation Conference Nuclear Energy for New Europe, Potoroz, Slovenia, 2016.

13. H. Bock. (2016, The TRIGA Mark-II Reactor.

14. H. Anglart, Applied Nuclear Technology and Nuclear Power Safety. KTH: Nuclear Reactor Technology Division Department of Energy Technology.

15. Syarip, Kinetics and Nuclear Reactor Control. Yogyakarta: Badan Tenaga Nuklir NAsional (BATAN), 2001.

16. A. Cahyono, D. Handoyo, K. Handono, and S. T. P, "Programming of Kinetic Reactor Equationn using LabVIEW" PRIMA, vol. 9, p. 8, 2012. 
